„Bohemistyka” 2019, nr 4, ISSN 1642-9893

Jindřiška SvOBODOVÁ

Eva NOVÁKOVÁ

Palacký University

\section{Verbal Aggressiveness in Communication in Media and Online. A Case Study of the TV Cooking Show Spread}

Keywords: Face, media and online communication, im/politeness, verbal aggression

\section{Abstract}

The paper discusses verbal aggressiveness and (im)politeness in media and online communication. The analysis focuses on transcriptions of communicative acts by participants of the TV reality Spread! ("Prostřeno!", a Czech version of the proparticipants of the TV reality Spread! ("Prostreno!", a Czech version of the pro-
gramme Come Dine with me) and viewers' comments in related online discussions.

The analysis indicated that the use of face-threatening acts was determined by a type of communicative interaction and interlocutors' social roles. Striving to construct a positive self-image, the participants in the show did not take the risk of losing their face due to usage of derogatory or vulgar expressions in face-to-face interactions.

The anonymous online discussions, on the contrary, did not pose any risk for the positive faces of the speakers; therefore, the interlocutors showed clear tendency to either appreciate and support, or attack the contestants as well as other speakers.

The structure of many private channels' TV listings illustrates the continuous popularity of programmes that can be generally classified as the genre of reality television. An essential ingredient of all these programmes is the communicative act by interlocutors who are mostly

${ }^{1}$ Zpracování př́íspěvku bylo umožněno díky finanční podpoře Filozofické fakulty Univerzity Palackého v Olomouci z fondu Studentské grantové soutěže IGA pro rok 2019 unknown individuals without any training in public speaking or other kinds of public performances.

The communicative act in these programmes has several levels: in Level, 1 the contestants in the show interact face-to-face. It is noteworthy that a crucial criterion for selecting the contestants is their predisposition to get involved in verbal conflicts which are quite probable - and even expected - to happen as a part of the show. Level 1 Act is transmitted to the viewers in Level 2 who had been traditionally perceived as passive consumers unable to join the communication; a boom in online technologies, however, allowed Level 2 Viewers to enter Level 3, i.e., internet forums for posting their feedback on the programme and giving their highly subjective, even expressive opinions.

The present paper focuses on Level 1 and Level 3 Acts to discuss the speaker's strategies that threaten the hearer's face. A corpus of data includes the records of ten episodes of the TV cooking competition Spread! (in Czech "Prostreno", an international version of the programme Come Dine with $\mathrm{Me}$ ), broadcast by the commercial channel Prima in November 2018, as well as the contents of the related online discussion sites. The aim of the analysis is to describe the means of intentional impoliteness and verbal aggressiveness employed either in face-to-face communication, or in de facto anonymous comments in the online discussions.

\section{Communicative Acts in Spread!}

A genre of reality television made media opened to the topics that had been traditionally discussed in private settings only. Čmejrková (Čmejrková, Hoffmannová 2011, p. 38), referring to the research in communication of English and German provenance, highlights the importance of methodological distinction between communicative immediacy and distance. ${ }^{2}$ Texts with high communicative immediacy,

\footnotetext{
${ }^{2}$ Koch and Oesterreicher (1985) in their paper Sprache der Nähe - Sprache der Distanz suggest that communicative acts with a high degree of distance are
} 
usually in the form of conversation, have a limited scope of influence and are used in non-public settings by communicative partners who are close one to another (friends, acquaintances); typically, these texts serve as tools for constructing social identity and discussing the topics of both personal and professional life. High communicative distance, on the contrary, is mostly related to the topics beyond interlocutors' personal, intimate experience, i.e., political, cultural and social issues. The present-day media - the private TV channels in particular - has witnessed a distinct shift from communicative distance to the acts previously restricted to private communication, that is to communicative immediacy.

Reflecting on the norms of communication, Raible (2002, online) points to the importance of conventions in a society and the relation of specific communicative acts (small talk, joke, gossip vs. job interview, sermon, court verdict) to the contexts defined by social conventions. Various text types represent a continuum which can be arranged as a scale with two end points: the interactive texts (conceptually oral, unplanned, not edited) and edited texts (conceptually oral, highly planned). Language is thus seen either as "an activity or process (involving present partners)", or as "something created, produced, edited, for instance a book" Raible (2002, online). Present-day media, however, seems to ignore the fact that it is the edited texts that should aim at a wide, non-specific audience: "Conceptually speaking, orality and literacy are thoroughly intertwined. The often postulated 'great divide' between orality and literacy, between 'oral' and 'literate' societies, simply does and cannot exist” (Raible 2002, p. 2).

Instead of consuming the edited texts in the outer communicative circle, a viewer of reality TV is drawn into an interactive text within the inner circle where the interlocutors act in their private settings and comment on the elementary, even banal everyday activities. Thus, as the genre of reality TV publicizes ordinary people, the media becomes

carefully planned, elaborated, and can embrace more interlocutors (cf. Čmejrková, Hoffmannová 2011, p. 38) more accessible to communicative immediacy and its topics discussing private, practically trivial issues.

As a result, Level 2 viewers listen to the discussions about how to look better and lose weight, cooking, housework, etc. The form of communicative acts is further modified by a format of the show: it can be controlled and regulated by presenters or remain independent on the external influence, with commentaries added later. Since the topics discussed by the contestants are banal and trivial, the authors of a programme must usually choose the strategies other than content to attract viewers' attention; for this reason, reality TVs accentuate the form and usage of specific linguistic means, in particular the expressions used by a contestant to evaluate the rivals and their activities. The contestants are encouraged to give an overt criticism, so they do not feel limited by the common norms of smooth and effective communication that prevent the speaker from threatening the hearer's face, ${ }^{3}$ and use highly expressive words with negative connotations.

\subsection{Online Communication of Reality TV Viewers}

Participants in online communication have free access to the forums where they can give their opinions on various issues without any external constraints, e.g., a presenter who selects a topic, gives the floor to the speakers or stops their speech in media communication. ${ }^{4}$

\footnotetext{
${ }^{3}$ Leech $(2014,21)$ quoting Lakoff $(1990,34)$ states that politeness is "a safeguard against disruptive forces in society". Lakoff herself $(1990,34)$ defines politeness as "a system of interpersonal relations designed to facilitate interaction by minimizing the potential for conflict and confrontation inherent in all human interchange". These definitions suggest that politeness in a socio-pragmatic perspective serves to launch and then facilitate a communicative act, while in reality TVs it becomes counterproductive: interlocutors compete to win a cash prize and their communicative achievements are not measured by politeness, but by the ability to assert their interests.

${ }^{4}$ Moderators of the forums can delete rude and hateful posts, but computer-assisted detection of unwanted content cannot prevent the user from cyphering a message, e.g., separating the characters of a pejorative word with meta-textual signs.
} 
Consequently, the public space starts absorbing more "speakers of the people" who may use online conversations (frequently senseless) to construct a new "virtual" identity without a risk of threatening their faces. Although these participants are not familiar one with another, nor maintain any close relationships, they are willing to discuss very private topics.

Regarding the online discussions on reality TV specifically, this level of communication (Level 3) consists of several layers: it is possible to distinguish active interlocutors (registered users of the forums who usually post their messages under a nickname) and passive interlocutors, who only read the posts, but do not participate in the conversations actively. The sublevel of active interlocutors involves the remarks on the content of the programme and the actions of contestants, as well as reactions on other posts. Consequently, Level 3 communicative acts are multiplied into the number of virtual exchanges of opinions.

Besides the unlimited number of interlocutors, an important feature of online communication is a temporal separation of some posts (for the purposes of the present study the analysis was limited to the posts preceding a deadline for viewers' voting on Friday evenings).

To sum up, Level 3 communicative acts are highly complex as for the number of interlocutors and the chronology of posts that can be followed in descending order, i.e., from the most recent messages to the previous ones.

\section{Impoliteness and Aggressiveness in Reality TV}

Impoliteness and verbal conflict are not phenomena native to online communication, and both have been a perpetual feature of human interaction (cf. Lehti et al. 2016). Offensive strategies that damage the hearer's face have received considerable attention in research on politeness and its opposites.

Nonpoliteness (Leech 2014, p. 216) involves a scale of strategies from a simple (often unintentional) lack of politeness to intentional at- tacks on the hearer's face; in other words, it is necessary to differentiate zero politeness, i.e., situations with no need for a speaker to be polite or impolite, from impoliteness when a speaker communicates face-attack intentionally. Moreover, judging the degree of (im)politeness always depends on interlocutor's individual assessment and other pragmalinguistic and sociopragmatic variables, e.g., speaker-hearer distance, age, sex, social status, etc. (Leech 2014, p. 218).

The fact that verbal interaction is seen as polite or impolite might be influenced by historical context and context of a communicative act, as well as by the interlocutors's individual interpretation. Locher and Watts $(2005$, p. 11) point out the entire continuum of verbal behaviour "from direct, impolite, rude or aggressive interaction through to polite interaction, encompassing both appropriate and inappropriate forms of social behavior". Last but not least, all communicative acts are assessed in terms of appropriateness, i.e., the social norms and verbal framing. Impoliteness is, therefore, understood as breaking the current social and communicative norms and threatening addressee's face.

\subsection{Face and Face Threatening Acts}

The face has been a key term in both pragmalinguistic and sociopragmatic research on communication (cf. Goffman 1967). The present-day concept of face is based on the assumption that each participant entering the social interaction claims for themselves an individual public self-image and wants to be perceived accordingly by others. Besides this positive face, there is a negative face, neglecting all factors which represent a threat towards individual rights and comfortto put it differently, a person requires their personal freedom and freedom of action. The face is not inherent to an individual, but is constructed with other participants of a communicative or social act, so it is the self-image formed partly by specific social attributes, partly by momentary relationships with others. This means that an individual 
might claim an indefinite number of faces depending on a particular communicative act:

Faces, in other words, are rather like masks, on loan to us for the duration of different kinds of performance (Locher, Watts 2005, p. 12).

The impoliteness (i.e., intentional nonpoliteness) in reality TVs does not necessarily have to lie in interlocutors' mutual relationships, but in each participant's tendency to make viewers accept his/his media image and to get viewer's support in a contest. Impolite behaviour thus means to attack another person's face and it is exhibited whenever a group of participants refuse to accept an individual's positive face, that is his/her positive personal and social attributes that are to be appreciated. In other words, the individual is denied the mask that he/she wanted to wear.

\subsection{Nonpoliteness, Impoliteness and Verbal Aggressiveness}

Nonpoliteness is not always conditioned by the speaker's intention to attack the hearer. However, the hearer who construes a message in terms of their subjective interpretative frames, experience, and expectations may decode it as impolite (or not polite enough), in spite of the speaker's positive communicative intentions.

The accidental impoliteness is, therefore, different from the speaker's deliberate attacks on the hearer's face and identity, i.e., offensive communicative acts to achieve the speaker's goals. Such type of behaviour in communicative acts can be labelled as verbal aggressiveness which is constructed either directly in the form of insults, verbal threats, mockery, etc., or indirectly as slander, laughing at somebody behind their back, etc. Aggression in general is a biological necessity to defend one's self, territory, natural resources and other individuals. As social behaviour developed, these instinctive motivations started to be controlled by rational norms that demand moral responsibility and self-control (for details see Lorenz 1969, pp. 247-262).

Considering communicative acts, the speaker constructs aggressive behaviour either in order to harm the hearer and lower their self-es- teem (this act is often meant as vengeance for the hearer's former harmful behaviour), or to gain advantage for the future, e.g., to confirm one's social status and satisfy one's needs, to be admired, to avoid an unwanted task, etc. In any case, the speakers act intentionally, although they may not use overtly aggressive verbal strategies such as expressive vocabulary (vulgarisms especially).

Verbal aggressiveness harms the hearer above all symbolically, so it is characteristic for such types of situations where a conflict is tolerated, or even expected. As a result, each participant might ascribe a different degree of importance to the act of harm.

Online environment gave verbal attacks and conflicts a new form: since the authors of online comments cannot be threatened by the hearers' reactions face-to-face, they feel free to use anonymous forums for direct, spontaneous, impetuous or harsh reactions to the online content. Although these sudden and intense conflicts, so-called flames (Lehti et al. 2016), are not an exclusively online phenomenon, they are less probable in real-life situations when an aggressor usually attempts to reduce the potential risk of a counter-attack. ${ }^{5}$ This does not mean, however, that a counter-attack cannot occur online, but due to the context of such communicative act the aggressor's face is threatened just minimally, in a symbolic way:

[1]

Jana: Slečna si koupí oloupanou zavakuovanou cibuli (at' žije životní prostředí, kéž by jí ty líne pracky uhnily)..a rozhodí ji když nenajde nůžky. Myslím že by si měla vyzkoušet obstarávat domácnost a hospodářství a čtrnáct dětí před sto lety. Ráno zatopit v kamnech, nanosit vodu, pro zeleninu dojít na zahrádku..

$\rightarrow$ Anonym: Ta Jana, nebude normální, vrat' se do jeskyně. Jinak si myslíme, že to je jen provokace od vtipálka, který ted’ čeká na reakce.

$\rightarrow$ Wardi: Ale madam, nežijeme přece ve středověku .......

$\rightarrow$ Iriiri: A Tys vykoukla z jeskyně, co???

Jana: The young lady buys vacuum sealed onion (long live the Earth, I wish her lazy hands rot away).. and then she's thrown off balance because she can't find the

\footnotetext{
${ }^{5}$ Impulsiveness is not limited to negative reactions, it can be used to show support and solidarity, too.
} 
scissors. I think she should try to manage a household and take care of fourteen children 100 years ago. Make fire in a stove, bring water, gather vegetables in the garden..

$\rightarrow$ Anonym: You're not sane, Jana. Go live in a cave. Otherwise everyone will think you're just joking to make others react.

$\rightarrow$ Wardi: Dear, this is not middle ages .....

$\rightarrow$ Iriiri: You've just left the cave, haven't you??

The author of the first comment (Jana) might never read the reactions, and if she does, her face is not threatened because nobody recognizes her true identity.

\section{Face Threatening Acts in Reality TV}

Impolite and aggressive communicative acts are linked directly to face threatening acts (FTA). The face was defined hereinabove as a variable of social relationships constructed during communicative interactions. A similar framework is proposed by Spencer-Oatey (2007) claiming that face can be understood comprehensively in terms of identity. Identity comprises a wide range of features, e.g., character, temperament, skills and competences, typical patterns of behaviour, social roles or identification with a social group. All these characteristics can be perceived as positive/negative, elementary/marginal, etc., depending on the context which is always defined by interlocutor's social role and social interaction.

Culpeper (1996) elaborates on the previous theories of positive and negative face by introducing positive and negative impoliteness. Positive impoliteness is the use of strategies designed to redress the addressee's positive face wants, for instance, to be disinterested in a topic chosen by the speaker, to select a sensitive topic which makes the hearer feel uncomfortable or embarrassed, use obscure or secretive language, use inappropriate identity markers or derogatory nominations ("call the other names"), etc. Negative impoliteness means to frighten, ridicule or trivialize the other, speak about information which is too intimate for the other, condescend, etc. (Culpeper 1996, pp. 357-358) In his later work, Culpeper (2011) uses a general term face which is, like for Spencer-Oatey, associated with various aspects of identity (relational identity, social identity, etc.).

The speaker's verbal acts attacking the hearer's face are assessed as impolite or aggressive. The attacker breaks the social norms and, as a result, harms, offends or belittles the hearer. These strategies might block the rational and effective communication, which is conditioned by the cooperation of participants. ${ }^{6}$

The cooking reality TV Spread! exemplifies a complex, multilayered interaction with several levels of communicative acts (see Introduction). At Level 1, each episode is opened by one competitor who, while preparing a menu, not only remarks on the procedure of cooking, but also expresses their opinions on other contestants and their performance. The next part shows contestants-guests as they arrive at the host's, inspect the house, comment on the furnishings, etc. Finally, the guests sit for the dinner and evaluate the quality of the menu. The dinner is framed by "small talk" which, however, deviates from the norms of this genre, including the typical role-making: as each contestant's primary motivation is to win, they tend to violate the requirements of avoiding embarrassing, unpleasant or conflictual topics. These interactions are interrupted by the scenes where the guests talk on camera, evaluating the menu.

Most FTAs identified in the present corpus threatened positive face of a host, i.e., depreciated the qualities of a perfect host and an excellent cook, which form the essence of cooking shows. For example, the hosts were criticised repeatedly for using artificial flavours; the criticism was projected into a verbal attack when a contestant was called derogatorily a stock powder.

\section{[2]}

I: jako když si to člověk přisolí tak ta polívka fakt je dobrá (...) honzík ji měl trošku silnější že? ji měl lepší

${ }^{6}$ The distribution of social roles can be so strict in some types of communicative acts, e.g., military drill, that the criteria above do not apply. The social context of reality TVs corresponds closely to these specific situations. 
R: měl ale on tam měl ten $(\ldots)^{7}$ víš tam dal -

J: to není tím. to tím není. silnější je tím když ji dýl taháš

J (na kameru): to že já sem včera dal bujón do polévky to nemá nic společného s tím jestli polévka bude silná nebo nebude silná. ten bujón je k tomu jenom aby to ochutilo

R: no tak já sem to tahal čtyry hodiny (...) jako tu polívku

J: mně připadá ta tvoje taková čirá

R: jo: v pohodě. normálně názory říkejte (...) v pohodě

J: no já sem měl silnější oka a to není jakože bujónem. bujón ti dodává jenom chut' to není tím že aby si měl silnou polívku

I: if you add a pinch of salt, the soup is fine (...) honzik's was a bit stronger, wasn't it? a bit better

R: well, but there was (. . .) you know he added -

$\mathbf{J}$ : that's not the reason. the longer you simmer, the stronger the broth is

$\mathbf{J}$ (on camera): it makes no difference that I added a stock powder yesterday, it cannot make the soup stronger. it's just for more flavour.

R: I was simmering it for four hours (. . .) that broth

$\mathbf{J}$ : this broth seems less thick to me

R: fine, put it frankly (. . .) no problem

J: there was more fat in my broth, but not due to the powder stock. the powder stock just makes more intense flavour, not a thick soup

Another type of FTA is related to the host's inability to serve the meals on time, without delay. Other contestants, although they might

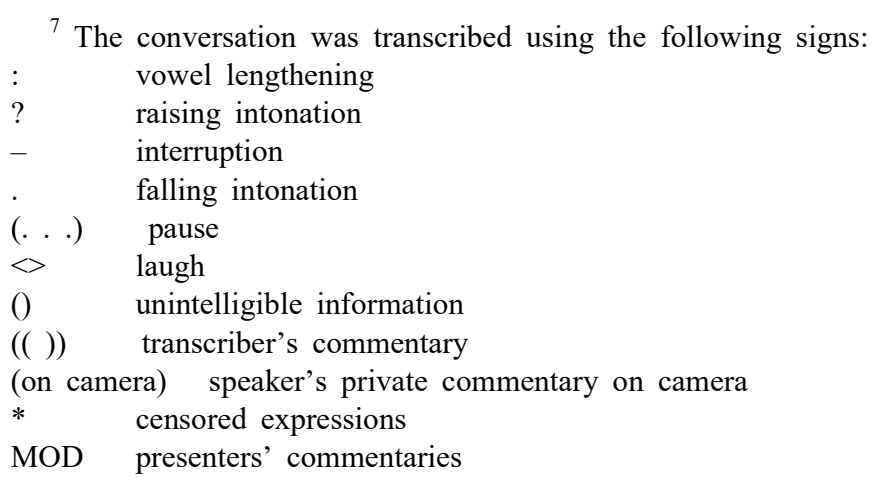

face the same problem themselves, do not hesitate to seize the opportunity for attack:

[3]

A: si šla pro tu rýži do ázije? ((tj. Asie)) ((smích))

R: na pole rýžové

J (na kameru): tak sme čekali na ten hlavní chod skoro půl hodiny. to tam trošku prostě se mi nelíbilo

R: honza už je nervózní?

J: z toho čekání

T: ((přichází z kuchyně)) už to je

A: už sem myslela že budu jak ve škole víš. my máme hlad! ((smích)) ne. Děkujem

A: you went to Asia to get the rice, didn't you? ((laugh))

R: to a paddy field

$\mathbf{J}$ (on camera): we waited for the main course almost half an hour. it was a bit disappointing

R: honza, what troubles you?

J: waiting for so long

$\mathbf{T}$ ((coming from the kitchen)): here we go

A: felt like at school. we're so hungry! ((laugh)) no, just kidding. thank you

[4]

I (na kameru): když už sme měli fakt strašný hlad na maso a už ř́kal asi desetkrát že za pět minut to bude tak přišel s tou zmrzlinou rozteklou (...) která vypadala úplně otřesně

D: není to už použitý?

\section{D + I + M: ((smích))}

T: já sem () nepoužil brčko

M: kde máś ty frajere? ty na to ani nemáš chut' vid’?

T: já sem (...) no já mám tamhle tekutej chleba. mně by to asi nešlo $\mathrm{k}$ chuti ted’ ((všichni kromě E se smějí))

D: $(<$ to není ani možný.)

I (on camera): we were terribly hungry, waiting for meat, he repeated ten times "five minutes left", and than he brought that melted ice cream (. . .) that looked horrible

D: haven't you served this before? 
D + I + M: ((laugh))

T: I did not () take the straw

M: and where's your plate? you don't feel like eating anymore, do you?

T: er (. . .) well, I have my liquid bread ((beer)) here. 'm afraid I wouldn't enjoy it now.

((everyone is laughing, except for E))

D: $(<$ this is too much $>)$

Third, guests belittle the host when they point out untidy rooms, stains on the tablecloth and the dishes, mistakes in setting the table, etc:

$[5]$

A: mám zat’áplou lžičku (...) aji skleničku

J: já též sklínku

I: ty nemáš vidličku?

A: já nemám vidličku ty vole

T: ty nemáš vidličku?

A: nemám

T: tys jí snědla možná

A: no tak já sem jedla ten ten (...)

R: já sem neměl uklizeno?

((chvíle ticha. R se usmívá a klepe prsty o stůl))

A: no dobré. nic

J: ((usmívá se)) no naklizeno vypadá trošku jinak jako. popravdě. takže asi tak ňák

R: ((povzdech)) jéžišmarja

A: když si nám vykládal že to byl jakože velký úklid -

J: no: a velkého úklidu to jako bylo hodně daleko

R: tak to ste neviděli ještě ten bordel předtím (...) takže to byl velký úklid jako

A: this spoon is not clean (...) and the glass either

$\mathbf{J}$ : the same for my glass

I: you don't have a fork?

A: I don't have any fork, dude

T: you don't have a fork?

A: no

T: so you swallowed it up, maybe
A: well, I was eating that (. . .)

R: you mean my flat is not neat and tidy?

((silence. R smiles and taps his fingers on the table))

A: well, easy

$\mathbf{J}$ ((smiling)): honestly, "neat and tidy" is something else, to put it gently

$\mathbf{R}$ ((sighs)): oh my

A: when you said it was a big clean-up -

$\mathbf{J}$ : yep, this is kinda far from a big clean-up

R: that's because you didn't see the mess before (. . .) so it was a big clean-up

Fourth, FTA is caused by the lack of tact and introducing unpleasant, private issues. The guests showed the lack of tact by asking the hostess repeatedly when her daughter was born to learn how old the hostess is:

[6]

J: tam sem viděl fotku př́tele a tvojí dcery. to je tvoje dcera?

A: hmmm jo to je moje

J: kolik má roků?

A: jedenáct

$\mathbf{R}$ : ale ty si ale mladá maminka

((všichni se smějí))

A: no

R: a kolik je tobě?

A: dvacet sedm

J: I saw a photo of your partner and your daughter over there. Is she your daughter?

A: yes, she is

$\mathbf{J}$ : how old is she?

\section{A: eleven}

$\mathbf{R}$ : what a young mom you are

((everyone is laughing))

A: yes

R: and you, how old are you?

A: twenty-seven 
Decoding of impoliteness always depends on the situational context, participants' individual experience, and especially the current social micro-net especially. The interlocutors, therefore, might interpret the situation as FTA just because they are not treated with respect, their social role is diminished and their self-image not appreciated. Example (7) describes the situation when the hostess decided to innovate the after-dinner entertainment and offered their guests psychological coaching:

[7]

E: ((jí porci, kterou si přidala. ostatní už mají prázdné taliǐe)) tak vlastně ted' by měl bejt moučník mezi tím. teda vlastně mezi moučníkem by měla bejt zábava. tak sem si říkala že bysme si každej o sobě něco mohli ř́ict. můžete se mě zeptat na co chcete. kde vás třeba tlačí bota

I: tak eliško tak jak to máme dělat s tím tlačením bot. mě tlačí boty jako hodně ale mám takový jako odlehčený téma aby to nebylo jako nudný (...) tak poradišs?

E: no jasně a v kterejch místech tě bolej ty nohy? jako prsty?

I: já to myslím jako obrazně. já sem myslela že ti řeknu jako téma který -

E: já myslela že tě opravdu bolej

Ostatní: ((smích))

I: nenene. mě nebolej nohy

E: no tak ale pro srandu tady nejsem

E: ((eats the second portion, the others have finished)) so now we should have a dessert. but, actually, first we should have some entertainment. so I thought that everybody could say something about themselves. you can ask me any question. like where your shoe pinches

I: fine, eliška, so what are we supposed to do with pinching shoes? my shoes pinch a lot, but I'd rather talk about something less serious instead, nothing boring (. . . .) so what would you advise me?

E: and where do you feel pain on your feet? you mean toes?

I: I mean it metaphorically. like that I could reveal to you what -

E: I thought you really suffer from some pain

((everyone is laughing))

I: nonono, my feet don't hurt

E: come on, I'm not here for your fun
The hostess' reaction shows that the joke was interpreted as the face attack. ${ }^{8}$ Similarly in (8) one of the guests gives a book to the hostess. As the recipient considers it a cookbook, she assumes that the guest alludes to her obesity and insinuates that she should improve her diet:

[8]

I: a já tady mám knížku. chtěla bych dneska rozvinout téma okolo tvýho zdravi abysme dotáhli tu diskuzi kterou sme minule nedotáhli a (potom) se ňák pobavili. tohleto není jako úplně jenom kuchařka ale není to jenom o vegetariánství. je to prostě o tom co jíst a (...) člověk si pak sám může vybrat

M: dobře. mockrát děkuju

M (na kameru)... nevím jestli mě chtěla urazit (...) ale: (...) nebylo mi to př́jjemné a (...) trošičku si budu dávat na ivču pozor

I: here is a book for you. I'd like to continue the talk about your health that we did not finish last time and (then) have a discussion. this is not just a cookbook, you know, and it is not about a vegetarian diet only. it's simply about what to eat (...) and you can make a choice of your own

M: OK, thank you

M (on camera): I'm not sure if she wanted to offend me (. . .) it made me uncomfortable and (...) I'm gonna watch out for her a bit

The hostess' interpretation of a friendly gesture as FTA is proved by her commentary on camera:

[9]

M: nelíbí se mi když mi někdo kecá v mejch letech do života. jestli to mám dělat tak nebo tak. jestli je to správný nebo není správný a (...) asi tady trošičku narazíme

M: regarding my age, I don't like when someone's trying to run my life. what I should and should not do. she might find herself in hot water soon

Damaging or attacking the hearer's face directly poses the risk that the hearer constructs a counter-attack that will threaten the speaker's face in return. Reality TV, however, allows contestants to share their

${ }^{8}$ The hostess was the oldest of the contestants and promoted a healthy lifestyle actively in the programme. For this reason she could interpret the reaction as an act of disrespect and denial of her personal qualities. 
opinions with a camera only, and hence instigates them to talk about the others behind their back:

[10]

J: ((bere do ruky díl modelu auta)) tu asi skládá radovan

T: mysliš že to je jeho koníček?

J: asi jo

T: a vidíš někde to slepené auto?

J: ne

J (na kameru): to tam bylo spíš jak takové skladiště. každá stěna vymalovaná jinak. jedno s druhým (...) takže nevím nelíbilo se mi to tam

T: má to vcelku tady pěkné. na ten malý prostor

J: sice každou stěnu jinačí (...) fialová. fialová tady. to je ňáká jiná fialová. asi mu nevyšla barva

T (na kameru): má to tady radovan chaotické. nemá tady nic na svojem místě. nevim nedovedu si představit mít takové bydlení

J: zatím jim to stačí no. tak jako fakt to tu mají jen na to přespání no. takže si myslím že v pohodě

$\mathbf{J}$ (examines a model car): radovan probably builds them

T: d'you think it is his hobby?

J: probably

T: and d'you see a finished car anywhere?

J: no

J (on camera): a flat looks like a warehouse. different paint on each wall, one thing and another (. . .) I don't know, I didn't like the place

T: it's not bad here, if you consider the limited space

$\mathbf{J}$ : just that each wall is different (...) violet. look at the violet colour here, it's different from the rest. maybe he ran out of the pain

T: it is so chaotic, nothing is in place. I couldn't live like that

J: probably it's all they need, just a place to sleep. so it's fine to me

Reluctance to enter the immediate conflict becomes evident when a contestant's opinion given on camera differs from their acting in the company of the others:

\section{[11]}

E (bokem): myslela sem že upeče svoji brusketu jako sama. no bylo to takový tvrdš ale neptala sem se proč neupekla svoje (...) nechtěla sem ji přivádět do ňákýho rozpaku

E (aside): I though she could make the bruschetta herself. this one was quite tough, but I didn't ask why she hadn't baked them herself (. . .) I didn't want to embarrass her

As the speakers are safe from negative reactions, slander is the most frequent strategy in this programme.

\section{Verbal Aggressiveness in Online Discussions}

In contrast to the face-to-face interaction, impoliteness constructed indirectly does not pose a risk of threatening face of the speaker. Consequently, the speakers show a greater tendency to use verbal attacks and offence whenever they feel sure about their anonymity, typically in online discussions.

[12]

(a) Tato paní IVA to pojala jako inzerát na seznamení. Inteligence ji opravdu chybí a hraje si na roztomilého, přestárlého diblíka. Trapná. Který muž by si ji vybral, bude blázen. Je vidět, že je zvyklá poroučet a děs, běs. Tohle mít doma asi NECHCE NIKDO :-)

(b) Tlustá paní, vy jste tak hnusná závistivá a hloupá osoba, že se z toho vašeho životního p růse.ru stejně nikdy nevyhrabete. A to vám teda garantuji. Jste ošklivá jak $\mathrm{z}$ venčí, tak zevnitř. Je mi z vás tak bl.bě, že mi ani nejde psát $\mathrm{v}$ oslovené velké "V". A to se mi často nestává. Může vám to být jedno, to chápu, ale uvidíte, že se moje slova budou plnit. ${ }^{9}$

(a) This woman, Iva, considers this to be a dating show. She really does not have any intelligence, she just pretends to be a cutie, but an overaged one. Painful. A man who would choose her is a fool. Evidently, she's used to command everybody, terrible. NOBODY would like to live with anyone like this.

(b) You fatty woman, you're so nasty, jealous and stupid that you'll never dig yourself out of these shi.ts, I guarantee. You're ugly both on the inside and the outside. You

\footnotetext{
${ }^{9}$ The posts were copied without any editing procedure, punctuation included.
} 
make me so sick that I cannot address you as "Dear", which I normally do. You may not care, I know, but you'll see my words will come true.

The authors of posts $(12 a, b)$ attacked the addressee by referring to the aspects of identity that are normally kept a taboo - the contestant's age and solitude, weight, appearance, low intelligence, etc.

The following part of the paper focuses on the online face threatening acts. The examples were selected from online discussions that followed the analysed episodes of Spread!. Since the platform is open and users can both add and delete their posts, the corpus contains only the messages that remained accessible after the viewers' voting had been closed.

The original corpus contained 350 pages, but the analysis itself was based only on the posts that commented on the contestants. Moreover, we excluded the repetitive messages with highly obscene content (evidently posted by one author with the same nickname) as well as the posts in the threads which concerned the participants very loosely or not at all, e.g., discussion on tooth care, health care, pension, performance of Olympic winner Ester Ledecká, vegetarian and vegan diet, etc.

Not unexpectedly, many posts were related to the programme directly; the users discussed contestants' voting on the best dinner party (especially the cases when contestants awarded the rival unfairly low score intentionally to secure their own victory), preparation of food, quality of meals, table manners, tidiness, and similar topics.

\section{[13]}

(a) Bože já ti fandila....mladá slečna, která umí dobře vařit a hlavně jak je fajn a př́ijemná. Odporná jsi ani nevíš jak každýho jen taktizuješ!! Zajímalo by mě jak by si taktizovala kdyby si vařila jako poslední. Jak už tu někdo psal: Jídlo jsi měla asi dorý, ale jako člověk jsi nechutná a odporná!!!! Češi totiž neumí nic jen taktizovat druhý....tohle by se jinde než v Česku nestalo!!!!

(b) Jak jsi zakrs.la tak jsi trap.na.. Jeste, zes nic nevyhrala..

(c) Plešounovi jde nejvíc o výhru, nic mu nejede, na nic nemá chut'. Klasická trapná taktika, ale zřjmě vyhraje.

(d) Plešoun taktizuje až moc. Nic mu nechutná. Má rozežranou hubu. Všude byl všechno zná. Dávám mu na tento týden míínus 10 (e) Do doby než uvařil byl normální chlap, který se snažil být př́ijemný. Dovařil a je z něj h.vado. A to se děje v Prostřenu dost často. Co je to za povahy nechápu.

(a) How I supported you at first.... A young lady who cooks well, is fine and nice. You don't even know how disgusting you are, you can only use tactics on the others. I'd wish to see your tactics if you had been the last host. Somebody wrote it before: your cooking might be good, but you are a disgusting and nasty person!!!! The Czechs cannot do anything but use tactics on the others... This could happen only in Czechia!!!!

(b) You're as shame.less as you're scraw.ny.. Serves you right you didn't win..

(c) Bald head cares only about his victory, he doesn't like anything, nothing is good enough. A classic awkward strategy, but he might win.

(d) Bald head strategizes too much. He doesn't like anything. He's a picky eater. $\mathrm{He}$ knows everything and everybody. I'm giving him miiinus 10 points this week.

(e) Before he hosted he'd been a normal kind of chap. Now he's finished and turned into an a.hole. You can see this quite often in Spread. I don't get it, these characters.

The viewers in (13) reveal their negative emotions in the expressive and damaging judgements. The contestants are referred to by negatively oriented metonymies (Bald head), vulgarisms (asshole) and the attributes that accentuate negative features of their identities (nasty, disgusting, scrawny, shameless). Cooking and table manners (example [14]) are, similarly, evaluated negatively with expressive modifiers and interjections:

[14]

(a) Měl jste to rozpatlané, nedala bych Vám ani 7 bodů.

(b) Vařená vepřová kýta v kečupovo hořčičné omáčce je pro mne věc nepoživatelná. Ale myslím, že někdo chtěl dokonce recept nebo hodně chválil. Tady je vidět, jak se Češi stravují a jaké blafy jedí. Brrr. :(

(c) Však ono to bylo nechutné ! Vývar kalný a ta přesolená krůta se škrobovou omáčkou? To bylo co ? Nechutnost.

(d) Jako přijat hosty v trenkách a vytahaném triku? Př́ípitek likér?! !Polévka hustší než omáčka, rizoto místo krémové suché. Nevím nad čím tady vzdycháte.

(e) Podravku v rozhudě nechápu. Vývar byl kalný, svítek nebyl svítek. Dušená roláda ve fólii bez výpeku, štáva zahuštěná škrobem je šílenost. Rozňahňané knedlíky na taliřrku nevypadaly vůbec dobře, a byl to v celém menu velmi těžký, hutný dezert. Za mě bych dala 4 body. 
(a) It was all mushy, I wouldn't get you more than 6 points.

(b) Pork leg stewed in mustard and ketchup seems inedible to me. But I think someone wanted a recipe or praised it at least. This shows what crap Czechs consume. Ugh! :(

(c) This was disgusting. The broth was turbid, and the oversalted turkey with starchlike sauce, what was that supposed to be?

(d) To welcome the guests in boxers and a stretched shirt? A liqueur for a toast? !A soup thicker than a sauce, dry risotto, not creamy. I don't know what you all appreciate.

(e) I don't understand artificial flavours in curd cheese spread. The broth was turbid, pancake strips were not what they should be like. Pork roulade in the wrap with no juice, to add starch into the gravy is crazy. Mushy dumplings on a plate did not look good at all, the menu was finished with a very heavy dessert. I would give 4 points.

Although the critical evaluations prevailed in the corpus, some users of the forum reacted to contestants' performance in a positive, supportive way. One of the Friday hosts, a viewers' favourite, was given predominantly positive comments:

[15]

(a) Gratuluji, paní Ivanko $\mathrm{k}$ výhře od diváků. Jsem ráda, že jsem vám také mohla dát 10 bodů. i když jste měla vyhrát př́mo vy. Ale celý národ vás miluje a to je super! No ne ? Mějte se krásně.

(b) Dobře jste uvařila, byla pohodová, usměvavá, milá a tak to má být. Fandím vám. Za mě 10 !

(c) Libilo se mi moc, jak si Terezka vedla v kuchyni, jidlo mela opravdu krasne nachystane na taliri. Kdyby se vsichni krasne vyoblekali, dalo by se rict, ze to je jidlo jak v 5hvezdickove restauraci :) Dala bych ji 10 bodu kdyby mi chutnalo.

(a) Congratulations to the viewers' prize, Ivanka. I was happy to give you 10 points, though you did not win in the end. The whole nation loves you and it is awesome! Isn't it? Take care.

(b) Your cooking was excellent, I like you're an easy-going, nice person, always beaming. You've got my support. 10 points!

(c) I liked the way Terezka was doing in the kitchen, the plates were set wonderfully. If everybody had had some fine clothes, it would have looked like a 5-star hotel dinner. I'd have given her 10 points if I'd liked the meal.

The tables below indicate clearly that most of the posts were not related to the matter of the show, but aimed at contestants' individual characteristics instead. Apart from the attacks on the physique and dressing (see example [14d]), viewers criticized contestants' intelligence or family relations:

[16]

(a) Nehezká, skrčená, hloupá a má obočí jak Marfuša a povahu taky. Hnus!

(b) Jak jsi zakrs.la tak jsi trap.na.. Jeste, zes nic nevyhrala...

(c) taky nevíš jak se obléct na slavnostní večeři? :-)

(d) Škaredá, primitivní, malá tlustá a nestará se o dítě. To je snůška předností této osoby. No Fuj tajxl.

(e) Ano, taková hodně jednoduchá osoba. Chápu, proč má dceru na stř́idačku.

(a) Ugly, cringing, stupid, with eyebrows and temper like Marfushka from Jack Frost. She sucks!

(b) You're as shame.less as you're scraw.ny.. Serves you right you didn't win.

(c) Don't you know what to wear for a dinner party? :-)

(d) Ugly, crude, short fatty and doesn't look after her child. That's a pack of strengths of this person. Phooey.

(e) Yes, she's quite simple. It's clear why she has shared custody of her child

FTAs were not necessarily constructed as vulgar or expressive utterances; the addressee's face could be damaged also by the attacks on their identity and impolite addressing. An example of the overt attack on physique cited above was not unique; there were more contestants mocked with expressive names or original similes:

[17]

(a) To napište té sádelnici, ta taktizovala a dávala nejméně bodů.

(b) Proc s tak nechutně odpornou chlapskou postavou odhaluje nedostaky - tluste paze? Sebevedomi ji tedy nechybi. V kuchyni si ale vedla zrucne.

(c) Paní není při těle ale tlustá jako prase v trenkách!

(d) Marcelo, takhle z profilu, jak sedíte u stolu, je vidět, že nejste tlustá, ale už obézní Měla byste s tím něco dělat. I s Vaší ukňouranou a ublíženou povahou, jinak zưstanete do konce života sama, se psem, který zabírá jednu stranu postele. Hodně smutný obrázek relativně mladé ženy....

(a) Send this to the fatty bitch who only used tactics and was giving the lowest score

(b) Why is she showing the shortcomings of her gross, manly figure - her fat arms? She does not suffer from a lack of confidence at all. But she was dexterous in the kitchen. 
(c) Not that she is plump, but fat as a pig in shorts!

(d) Marcela, when you sit at the table in profile, it's clear that you're not fat, but obese! You should change it as well as your whiny and hurt character. Otherwise you're going to be alone for the rest of your life, except for the dog that occupies the other side of your bed. It's a sad image of quite a young woman...

Other critical remarks applied to a contestant who suffered from alcoholism evidently ( $A$ few beers will turn him into a really nice guy! :-) :-) I don't like idiots and alcoholics, that's the matter.), contestants' ill humour (She would curdle new milk. . . He's such a spoilsport. Negativism falls of her like autumn leaves. Away from her. Girl, it's time for a change.), etc.

Some statuses show little tolerance, even racism, as in case of addressing a Roma contestant:

\section{[18]}

(a) Trapné chování po tom co už měl odvařeno. Je to odporný upocený cigo!!

(b) Tihle „hnědočeši“ mají jak vidno silný žaludek.

(c) Ze Slovenska k nám může přijít medvěd, nebo tahle temná rasa. Já beru medvěda. (d) vyhraje ulhaný k.i.k.á.n, Terezy zábava se mu zdála průměrná, za to lézt na komín je terno. Copak měl tenhle člověk za neštěstí v rodině a nepodělil se s námi o něj?

(a) After he had hosted the party, he was embarrassing. He's a stinky, sweaty gyppo.

(b) These "brown Czechs" have strong stomachs, apparently.

(c) Only two things can come from Slovakia - a bear, or this dark race. I prefer the bear.

(d) Cheaty g.y.p.p.o is going to win. He found the after-dinner entertainment at Tereza's average, and now he thinks it's a great fun to climb a chimney. Perhaps he was stricken by some family tragedy he did not reveal to us.

Furthermore, aversion aimed at a contestant who revealed her homosexuality (She's lesbian for sure . . looks like a c.u.n.t . . in these manly shorts . . . she doesn't know how to dress for the dinner! Tereza is the lesbian who cannot treat people, nor animals. She considers herself to be awesome but she's a fat and very simple girl in fact. As far as I know, she doesn't do anything for a living and she's always eaten meat.) or vegetarianism (When I look at that dried mummy, I see clearly why I can never be vegetarian.). These statements indicate viewers' reluctance to accept the differences. Many negative comments were addressed to a contestant talking openly about her poor health which was the reason to terminate her stay in USA. The negative opinion in (19) is expressed as stylized astonishment with the sequence of rhetorical questions, the diminutive (owie, "bebínko"), and the simile (as cunning as a fox):

[19]

Hmmm, zajímavé.... Do Ameriky jít vydělávat, ale jak máme bebínko, tak honem honem domů $\mathrm{k}$ doktorovi... Pročpak si nejde $\mathrm{k}$ doktorovi v Americe? Tady to má zdarma, že? Nebo jí to zaplatíme my... A pak honem honem do USA... Vyčuraná jako díra do sněhu...

Well, interesting.... Moving to America to make money is fine, but as soon as she gets an owie, she hurries home to see the doctor... Why doesn't she see him in USA? But isn't it for free at home? Or paid by us... And then hurry up! back to USA... As cunning as a fox...

The highest number of comments was sent to a contestant who, apart from being vegetarian, confessed that she possesses a figurine of a small boy that she considers her real son (it kept her company on holiday, was supposed to go to university, etc.). The majority of viewers criticized the contestant's identity by questioning her sanity:

\section{$[20$}

(a) Bába asi nebude ani zlá, ale vypatlaná je těžce.

(b) Myslím, že paní to má v hlavě poskládané trochu jinak. K panence se chová jak $\mathrm{k}$ dítěti, kdyby jí bylo o 70 let méně, tak mě to nepřekvapí, ale takhle? A její zábava mě opravdu pobavila, všichni z ní byli opravdu mimo.

(c) Ta pomatená ženská by se měla spíš hlásit k psychiatrickému sezení a ne do pořadu o vaření. No a neměla by zapomenout vzít sebou toho gumového panáka, co půjde studovat! To je fakt síla, co za sračky ta TV dokáže odvysílat.

(a) This old woman might not be mean, but she's brainless for sure.

(b) I think the lady is not quite right in the head. She treats the doll as a child, if she was 70 years younger, it would be OK, but like this? I really enjoyed her party programme, everybody freaked out completely.

(c) This insane woman should register with a psychiatrist, not at a cooking show. And she should not forget to bring with her the rubber guy that's going to university. It's ridiculous what a shit is broadcast on TV. 
FTAs in (20) involve expressive vocabulary (old woman, insane woman) and references to the contestant's age.

Next, the evaluative posts were constructed as rude and vulgar comments, resulting probably from the unwanted outcome of the contest; there was an evident tendency to maximize the damage and mockery:

[21]

\section{inkvizitor (Anonym)}

Co jste od ní čekali? Vymletá trubka se nechala zbouchnout 15 a vrhla spratka. To takhle bývá, u spodiny, že se množí jako králíci. Bohužel, je to tahle hloupá spodina, co by se vůbec množit neměla! Kdyby ta špína jednou za čas otevřela oči, myslela hlavou (a ne prd.elí jak ted'), tak mohla vyhrát ta pravá. Ne, výhru si vydyndal špek jen kvůli tomu, že mu zkapal synáček...

\section{inquisitor (anonymous)}

What did you expect? The stupid cunt got knocked up at 15 and littered a bastard. Scum like this normally breed like rabbits, unfortunately, but they should not breed at all! If she thought with her head (instead her a.ss) from time to time, she could have won justly. No, it is the fatass that managed to beg the prize, only because his son had died.

The author, under the marked nickname inquisitor, used highly expressive and vulgar expressions to refer to the contestant's social status (scum), elaborated on a stereotypical idea of the destitute's undesirable fertility (to breed like rabbits), and gave the addressees dysphemic names (stupid cunt, fatass).

The tables below give the quantitative summary of viewers' evaluating the individual contestants, and indicate the ratio of positively and negatively oriented comments as well as the aspects of identity that were attacked most frequently.

Hostess: Adriana
\begin{tabular}{|l|c|}
\hline Monday 12th November & Frequency \\
\hline $\begin{array}{l}\text { Attacks on the individual personal features (physique, low intelligence, family } \\
\text { relations) }\end{array}$ & 114 \\
\hline Harsh attacks and offence & 25 \\
\hline Negative evaluation of the score given to the rivals, behaviour, clothing & 24 \\
\hline Negative evaluation of the menu and cooking & 32 \\
\hline Positive evaluation of the menu and cooking & 8 \\
\hline
\end{tabular}

\section{Host: Ján}

\begin{tabular}{|l|c|}
\hline Tuesday 13th November & Frequency \\
\hline $\begin{array}{l}\text { Attacks on the individual personal features (tendencies to demand rivals' sym- } \\
\text { pathy on the death of his son, pointing out his own health problems, obesity) }\end{array}$ & 88 \\
\hline Harsh attacks and offence & 37 \\
\hline Negative evaluation of the score given to the rivals & 10 \\
\hline Negative evaluation of the untidy house, inappropriate clothing & 62 \\
\hline Negative evaluation of the menu and cooking & 16 \\
\hline Positive evaluation of the menu and cooking & 17 \\
\hline Racist attacks & 11 \\
\hline Negative evaluation of undeserved victory & 19 \\
\hline
\end{tabular}

\section{Host: Radovan}

\begin{tabular}{||l|c|}
\hline Wednesday 14th November & Frequency \\
\hline Attacks on the individual personal features (alcoholism) & 36 \\
\hline Negative evaluation of cooking and table manners & 36 \\
\hline Positive evaluation of the menu and cooking & 35 \\
\hline Negative evaluation of the score given to the rivals & 12 \\
\hline
\end{tabular}

Negative evaluation of the score given to the rival

\section{Hostess: Tereza}

\begin{tabular}{|l|c||}
\hline Thursday 15th November & Frequency \\
\hline $\begin{array}{l}\text { Attacks on the individual personal features (obesity, inappropriate clothing, les- } \\
\text { bian orientation, vegetarianism, the return from abroad due to health problems, } \\
\text { "abusing" the healthcare system) }\end{array}$ & 63 \\
\hline Harsh attacks and offence & 2 \\
\hline Negative evaluation of the score given to the rivals & 5 \\
\hline Negative evaluation of the menu and cooking & 8 \\
\hline Positive evaluation of the menu and cooking & 29 \\
\hline Positive evaluation of the individual personal features, supportive messages & 32 \\
\hline
\end{tabular}

Positive evaluation of the individual personal features, supportive messages

\section{Hostess: Ivana}

\begin{tabular}{|l|c|}
\hline Friday 16th November & Frequency \\
\hline Positive evaluation of the menu and cooking & 14 \\
\hline Belief that the contestant should have won & 28 \\
\hline
\end{tabular}


Generally positive evaluation

Negative evaluation of the menu and cooking

110

\section{Hostess: Eliška}

\begin{tabular}{|l|c|}
\hline Monday 19th November & Frequency \\
\hline Negative evaluation of the menu and cooking & 18 \\
\hline Negative evaluation of the after-dinner entertainment & 4 \\
\hline Negative evaluation of the contestant's relationship to Hugo (the doll) & 58 \\
\hline Positive evaluation of the contestant's relationship to Hugo (the doll) & 10 \\
\hline Negative evaluation of vegetarianism & 56 \\
\hline Positive evaluation of vegetarianism & 4 \\
\hline Negative evaluation of the contestant's mental state & 58 \\
\hline Negative evaluation of the score given to the rivals & 23 \\
\hline Positive evaluation of the individual personal features / supportive messages & $33 / 40$ \\
\hline
\end{tabular}

\section{Hostess: Daniela}

\begin{tabular}{|l|c|}
\hline Tuesday 20th November & Frequency \\
\hline Attacks on the individual personal features (obesity) & 95 \\
\hline Harsh attacks and offence & 11 \\
\hline Negative evaluation of behaviour and the score given to the rivals & 56 \\
\hline Negative evaluation of the menu and cooking & 17 \\
\hline Positive evaluation of the menu and cooking & 29 \\
\hline Positive evaluation of the individual personal features / supportive messages & $71 / 35$ \\
\hline
\end{tabular}

\section{Hostess: Marcela}

\begin{tabular}{|l|c|}
\hline Wednesday 21st November & Frequency \\
\hline $\begin{array}{l}\text { Attacks on the individual personal features (negativism, pessimism, sense } \\
\text { of aggrievement) }\end{array}$ & 102 \\
\hline Harsh attacks and offence & 7 \\
\hline Negative evaluation of the score given to the rivals & 20 \\
\hline Negative evaluation of the menu and cooking & 18 \\
\hline Positive evaluation of the menu and cooking & 15 \\
\hline Positive evaluation of the individual personal features / supportive messages & $11 / 20$ \\
\hline
\end{tabular}

\section{Host: Tomáš}

\begin{tabular}{||c|c|}
\hline Thursday 22nd November & Frequency \\
\hline $\begin{array}{l}\text { Attacks on the individual personal features (alcoholism, exploitation of his } \\
\text { parents) }\end{array}$ & 33 \\
\hline Harsh attacks and offence & 1 \\
\hline Negative evaluation of the score given to the rivals & 3 \\
\hline Negative evaluation of the menu and cooking & 16 \\
\hline Positive evaluation of the menu and cooking & 1 \\
\hline Positive evaluation of the individual personal features / supportive messages & $17 / 11$ \\
\hline
\end{tabular}

\section{Hostess: Iva}

\begin{tabular}{|l|c|}
\hline Friday 23rd November & Frequency \\
\hline $\begin{array}{l}\text { Attacks on the individual personal features (untidy house, the debt of the house } \\
\text { and the risk of foreclosure) }\end{array}$ & 103 \\
\hline Harsh attacks and offence & 5 \\
\hline Negative evaluation of the menu and cooking & 19 \\
\hline Positive evaluation of the menu and cooking & 28 \\
\hline Positive evaluation of the individual personal features / supportive messages & $92 / 19$ \\
\hline Negative evaluation of the results of the contest & 13 \\
\hline
\end{tabular}

\subsection{Exchanges in Online Discussions}

As mentioned above, online communicative acts can be constructed either as the comments on the shared content in the form of "monologues", or the virtual exchanges between more interlocutors. Interlocutors from the present corpus followed similar patterns in both types of the acts - they expressed their negative viewpoints and attacked the addressee's communicative competences and intellectual skills:

Souhlasím s: (Anonym) 21.11.2018 20:08: Marcela je zamindrákovaná, negativní, protivná paní, která se patlá jen ve své minulosti a chorobách. Evidentně ale bídou netrpí, viz barák a nejnovější vybavení, gelové nehty atd., tak proč si pořád stěžuje na hrozný život. 
$\rightarrow$ Anonym (Anonym) 21.11.2018 20:16: Jestli hodnotíte spokojený život jen podle baráku a gelových nehtů, tak to tedy od života moc nechcete, takovým lidem se ř́ká chudý duchem, v hlavě nic.

I Agree With Anonymous (21st Nov 2018 20:08): Marcela is a frustrated, negative, annoying person who only fiddles about the past and her diseases. But she's not stricken by poverty obviously, see the house and brand-new furnishings, gel nails etc., so why does she keep complaining about the bad life.

$\rightarrow$ Anonymous (21st Nov 2018 20:16): If you measure the happiness by houses and gel nails, you don't want much from life. People like you are called the poor in spirit, empty minds.

In contrast to the discussions on the content of the reality $\mathrm{TV}$, these exchanges showed a lower occurrence of damaging and aggressive posts; example (23) demonstrates mutual agreement among the interlocutors:

[23]

\section{ehromasova 12.11.2018 18:28}

...to je vrchol buranismu jít mezi lidi v maskáčovým tílku a šortkách.. nebo právě přišel z ryb ?!

\section{$\rightarrow$ psenicamilan 12.11.2018 18:45}

Supéééér....!!!!

\section{$\rightarrow$ alena.sd 12.11.2018 18:30}

Přesně to samé mě napadlo. Nechápu, že někdo vůbec může takhle přijít na večeři.

A pak na druhou stranu chtějí netradiční nebo luxusní jídlo, ale oblečou se jak

$\mathrm{k}$ táboráku.

$\rightarrow$ nohelovaiva 12.11.2018 18:35

......už jen špekoňa do ruky......

\section{ehromasova (12th Nov 2018 18:28):}

... it's the top hick manners to wear a camouflage T-shirt and shorts for a dinner.

or has he just returned from fishing?

\section{$\rightarrow$ psenicamilan (12th Nov 2018 18:45):}

Cooooool...!!!

\section{$\rightarrow$ alena.sd (12th Nov 2018 18:30):}

That's just what I thought. I don't understand that someone can come dine like this. Dressed like for a camp fire, but they require the unusual or exclusive meal. $\rightarrow$ nohelovaiva (12th Nov 2018 18:35):

......he only lacks a sausage in his hand......

This type of online comments falls into the genre of gossips which is normally used by friends or acquaintances to discuss the everyday issues (Raible 2002). The genre traditionally related to high communicative immediacy therefore invades the public settings. Although the interlocutors do not know each other, they use linguistic expressions typical for communicative immediacy in private settings, e.g., a substandard code and sound symbolism.

In the last category of posts, the authors react to potential aggressiveness of other interlocutors and, reflecting the communicative distance of the public settings, urge them not to lose self-control:

[24]

Rituš (Anonym) 16.11.2018 16:45

Lidi ale proč jste tak zlý a vulgární ? Ano paní je závistivá atd . ale tolik urážek ..

\section{lenka.plancarova 12.11.2018 22:38}

Nechápu lidi když pisou komentáře co je spatne nebo co se jim nelíbilo a nedokážou se podepsat pořád jen ano nyní tak tam běžte a zkuste si to frajeři

\section{olgadol (Anonym) 21.11.2018 20:0}

Vždy, když si přečtu takový komentář, přemýšlím nad tím, proč jej autor vůbec napsal. Proč měl potřebu jej zveřejnit.

Kdo vám, UJJJ, dal právo někoho tak odporně škatulkovat?

Ano, je to anonymita. Proč by měla být falešná? Znáte ji osobně? Já ne. Proč tlustá? Spoustě lidí je jistě sympatická - znáte to: někdo má rád holky, někdo zase...doplňte si sám $/ \mathrm{a}$.

Prostě to shrnu: trapný jsi a zlý...tvé překlepy neřeším, ačkoliv bych se mohla vysmívat, proč si to po sobě alespoň nepřečteš, chudáku!!!!

\section{Rituš (16th Nov 2018 16:45):}

Guys, why are you so mean and vulgar? Yes the lady is jealous etc . but why so many insults ..

lenka.plancarova (12th Nov 2018 22:38):

I dont get the people who post the comments on what is wrong or what they didnt like and they dont say their name so go there and try it on your own, tough guys

olgadol (21st Nov 2018 20:05):

Any time I read a similar comment I think why the author wrote it and felt the need to post it...

Who gave you, UJJJ, the right to label people so nastily? 
Yes, it is anonymous. But why should she be false? Do you know her in person? I don't. Why fat? Many people may like her, you know the proverb To each his own. To sum up: you're ridiculous and mean...no comment on your typos, though I could mock that you cannot even revise what you wrote, loser!!!!

The authors who intuitively identify the causes of aggressive and harmful strategies realize that the anonymous online environment and construction of a new identity may incite the interlocutors to flout the norms of polite interaction. Moreover, this criticism involves the assessment of spelling and style in the respective posts.

\section{Conclusions}

The analysis of the corpus confirmed the hypothesis that if the interlocutors can communicate anonymously, their verbal aggressiveness increases. TV media and online environment make it possible for the speakers to use the interactive texts, normally constructed as the acts of private communication (here gossips and subjective evaluation of communicative partners), in public settings. The choice of expressions and communicative strategies, however, still depends on the particular type of medium and the situational context which it creates:

Participants in reality TVs who construct the communicative acts in face-to-face interaction with the others react to the social context established by the show: each contestant is highly motivated by his/her wishes to win, and therefore is making effort to convince all participants (Level 1 contestants as well as Level 2 viewers) of his/her positive face. Since the contestants might be threatened by the loss of face resulting from the open confrontation (and, consequently, might run a risk to be awarded few points in return), they avoid the direct attack usually; instead, they prefer slandering, which is a part of the show and the act that the contestants are incited to carry out.

The online discussions, on the other hand, are the medium the anonymity of which encourages interlocutors to evaluate and criticize openly. Since such environment protects users from the potential loss of their own face, the viewers of the reality TV use it to threaten the faces of the contestants with gossips or harsh and rude vocabulary. The most frequent attacks aim at various aspects of the positive face (e.g., a contestant's cooking skills), and however different they are for each contestant, they mostly reflect viewers' reluctance to accept the specifics of the individual.

In addition to the evaluative comments and statuses, the online discussions include dialogues of the users. They often simulate the communicative acts characteristic for private settings where the interlocutors construct gossips, a genre with high communicative immediacy, although they do not know each other. Some users, nevertheless, remain conscious of the public character of online settings: they try to correct both content and style of other authors' posts and urge them to keep their judgements polite. The hypothesis about the high frequency of aggressive and harmful strategies on Level 3 was thus partly confirmed, but some comments suggested the continuous tendency to respect the principles of communicative appropriateness and politeness.

\section{References}

Brown P., Levins on S., 1987, Politeness. Some Universals in Language Usage. Cambridge: Cambridge University Press.

$\mathrm{C}$ u 1 p e p e r J., 1996, Towards an Anatomy of Impoliteness. Journal of Politeness Research 25, 1996, 349-367.

$\mathrm{Cu} 1 \mathrm{p}$ e p e r J., 2008, Reflections on Impoliteness, Relational Work and Power. In D. Bousfield - M. Locher (eds.), Impoliteness in Language. Studies on its Interplay with Power in Theory and Practice. Berlin: Mouton de Gruyter, s. $17-44$.

$\mathrm{C} \mathrm{u} 1 \mathrm{p}$ e p e r J., 2011, Impoliteness, Cambridge: Cambridge University Press.

Čmejrková S., Hoffmannová J. (eds.), 2011, Mluvená čeština: hledání funkčního rozpětí. Praha: Academia.

G o f f m a n E., 1967, Interactional Ritual: Essays on Face-to face Bahavior. Garden City, NY: Doubleday.

H i r s c h o v á M., 2017, Nezdvořilost. In: P. Karlík, M. Nekula, J. Pleskalová (eds.), CzechEncy - Nový encyklopedický slovník češtiny. Online: https://www. czechency.org/slovnik/NEZDVOŘILOST [přístup: 24. 3. 2019].

L a k of f R.T., 1990, Talking power. The politics of language in our lives. Glasgow: HarperCollins.

L e e c h G.E., 2014, The Pragmatics of Politeness. Oxford: Oxford University Press. 
L e h t i L. (and others), 2016, Linguistic analysis of online conflicts: A case study of flaming in the Smokahontas comment thread on YouTube. Online: http:// widerscreen.fi/assets/Lotta-Lehti-et-al2-1-2-2016.pdf [prístup: 17. 3. 2019].

L o c h e r M.A., W a t t s R.J., 2005, Politeness theory and relational work. Journal of Politeness Research 1, s. 9-33.

R a i b le W., 2002, Literacy and orality. In: N. J. Smelser, P. B. Batles (eds.) International Encyclopedia of social and behavioral sciences, 2012, s. 8967-8971. Online: http://www.romanistik.uni-freiburg.de/raible/Publikationen/Files/ Orality 2col.pdf [př́stup: 17. 1. 2012].

$\mathrm{S}$ p e n c e r - O a t e y H., 2007, Theories of Identity and the Analysis of Face. Journal of Pragmatics 39/4, s. 639-656. 